\title{
Rural Electrification and Livelihood Generation for Women Enterprises in Rural India: Experience of Implementing Two-Stage Biomass Gasifiers
}

Dhingra, Sunil; Tanvir, Barkha; Henriksen, Ulrik Birk; Jaboyedoff, Pierre; Sinha, Shirish; Ziegerer, Daniel

Published in:

Technologies for Development: From Innovation to Social Impact

Link to article, DOI:

10.1007/978-3-319-91068-0_10

Publication date:

2018

Document Version

Publisher's PDF, also known as Version of record

Link back to DTU Orbit

Citation (APA):

Dhingra, S., Tanvir, B., Henriksen, U. B., Jaboyedoff, P., Sinha, S., \& Ziegerer, D. (2018). Rural Electrification and Livelihood Generation for Women Enterprises in Rural India: Experience of Implementing Two-Stage Biomass Gasifiers. In S. H., S. N. B., \& J-C. B. (Eds.), Technologies for Development: From Innovation to Social Impact (pp. 113-124). Springer. https://doi.org/10.1007/978-3-319-91068-0_10

\section{General rights}

Copyright and moral rights for the publications made accessible in the public portal are retained by the authors and/or other copyright owners and it is a condition of accessing publications that users recognise and abide by the legal requirements associated with these rights.

- Users may download and print one copy of any publication from the public portal for the purpose of private study or research.

- You may not further distribute the material or use it for any profit-making activity or commercial gain

- You may freely distribute the URL identifying the publication in the public portal 


\title{
Chapter 10 \\ Rural Electrification and Livelihood \\ Generation for Women Enterprises in \\ Rural India: Experience of Implementing \\ Two-Stage Biomass Gasifiers
}

\author{
Sunil Dhingra, Barkha Tanvir, Ulrik Birk Henriksen, Pierre Jaboyedoff, \\ Shirish Sinha and Daniel Ziegerer
}

\subsection{Introduction}

As part of the project, a two-stage gasifier of $20 \mathrm{kWe}$ capacity, with simple cleaning and cooling system, has been developed, tested and localized to Indian conditions. The experience so far has demonstrated high-quality gas $\left(\operatorname{tar}<25 \mathrm{mg} / \mathrm{m}^{3}\right.$ ), low specific fuel consumption, and no wastewater generation in cleaning and cooling. Table 10.1 shows the efficiency of the two-stage gasifier system developed in cooperation between The Energy and Resource Institute (TERI) and Technical University of Denmark, and Fig. 10.1 shows the process flow diagram of the system.

\author{
S. Dhingra $(\bowtie) \cdot$ B. Tanvir \\ The Energy and Resources Institute (TERI), New Delhi, India \\ e-mail: dhingras@teri.res.in \\ B. Tanvir \\ e-mail: barkhatanvir@gmail.com \\ U. B. Henriksen \\ Technical University of Denmark (DTU), Copenhagen, Denmark \\ e-mail: ubhe@kt.dtu.dk \\ P. Jaboyedoff \\ Effin Art, Lausanne, Switzerland \\ e-mail: pierre.jaboyedoff@effinart.ch \\ S. Sinha $\cdot$ D. Ziegerer \\ Swiss Agency for Development and Cooperation (SDC), New Delhi, India \\ e-mail: shirish.sinha@eda.admin.ch \\ D. Ziegerer \\ e-mail: daniel.ziegerer@eda.admin.ch \\ (C) The Author(s) 2018 \\ S. Hostettler et al. (eds.), Technologies for Development, \\ https://doi.org/10.1007/978-3-319-91068-0_10
}


Table 10.1 Efficiency improvements in two-stage gasifier

\begin{tabular}{|c|c|c|c|}
\hline Key parameters & $\begin{array}{l}\text { Fixed-bed } \\
\text { gasifier }\end{array}$ & $\begin{array}{l}\text { Two-stage } \\
\text { gasifier }\end{array}$ & Improvements \\
\hline \multicolumn{4}{|l|}{ Energy efficiency } \\
\hline $\begin{array}{l}\text { Overall efficiency (in } \\
\text { terms of biomass } \\
\text { consumption to } \\
\text { electricity generated) }\end{array}$ & $15 \%$ & $>22 \%$ & $\begin{array}{l}\text { About } 50 \% \text { efficiency gain due to } \\
\text { reduction in parasitic loads and } \\
\text { reduction in fuel consumption }\end{array}$ \\
\hline \multicolumn{4}{|l|}{ Resource use efficiency } \\
\hline $\begin{array}{l}\text { Input fuel } \\
\text { moisture-quality of } \\
\text { biomass that can go } \\
\text { as an input }\end{array}$ & up to $15 \%$ & up to $30 \%$ & $\begin{array}{l}\text { Greater flexibility in terms of } \\
\text { biomass quality (dry) and use }\end{array}$ \\
\hline \multicolumn{4}{|l|}{ Environmental benefits } \\
\hline Tar (raw gas) & $500-600 \mathrm{mg} / \mathrm{Nm}^{3}$ & $\begin{array}{l}\text { Less than } \\
25 \mathrm{mg} / \mathrm{Nm}^{3}\end{array}$ & $\begin{array}{l}\text { Impurities in the raw gas in form } \\
\text { of tar significantly reduced. This } \\
\text { improves the overall environment } \\
\text { performance of the system as less } \\
\text { tar is generated }\end{array}$ \\
\hline $\begin{array}{l}\text { Gas cooling and } \\
\text { cleaning system }\end{array}$ & $\begin{array}{l}\text { Water scrub- } \\
\text { bing- } 350 \mathrm{~L} \text { of } \\
\text { fresh water for } \\
50 \mathrm{~h} \text { of operation }\end{array}$ & $\begin{array}{l}\text { Without water } \\
\text { scrubbing }\end{array}$ & $\begin{array}{l}\text { Zero water usage for removing } \\
\text { impurities in the gas }\end{array}$ \\
\hline $\begin{array}{l}\text { Wastewater } \\
\text { generation }\end{array}$ & $\begin{array}{l}350 \mathrm{~L} \text { after } 50 \mathrm{~h} \\
\text { of operation }\end{array}$ & $\begin{array}{l}\text { No wastewater } \\
\text { generation }\end{array}$ & \\
\hline
\end{tabular}

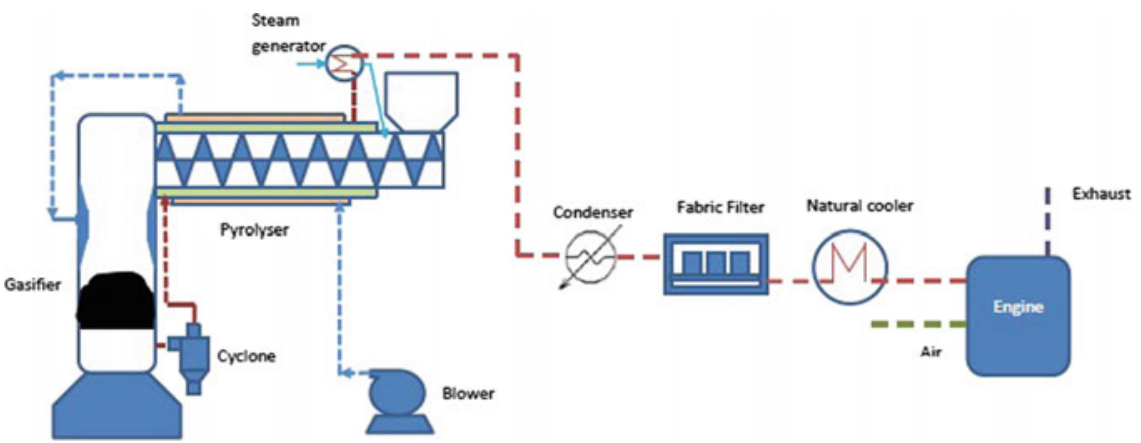

Fig. 10.1 Two-stage gasifier system process flow diagram

\subsection{Research Objectives and Involvement of Public Sector}

Lessons learnt from past experiences showed the need for a robust business model to support the economics of running of a gasifier with minimal maintenance and suitability for field implementation. Due to low income and high electricity subsidy 
in rural areas through conventional grid system, it is becoming challenging to support renewable energy-based electrification projects, particularly based on biomass resource on account of high fuel and labour costs. Utilizing the energy from the gasifier for only rural household electrification led to non-payment towards the functioning of the gasifier due to lack of incentive (World Bank 2011).

The project has developed a new approach with focuses on developing business models by combining energy-driven economic activities and meeting household energy requirements in villages in regions of India. With community-based activity getting regular electricity to run successfully, the operation cost of the gasifier towards fuel and operator salary is met and, hence, can also electrify the villages around it. The project model is such that the gasifier will run during daytime providing electricity to the micro-enterprises and in the evening, when lighting needs of households are highest, the gasifier will supply electricity to the households in the nearby villages.

The project has identified around 20 potential sites in the states of Odisha, Jharkhand and Madhya Pradesh, and shortlisted four sites for field implementation of twostage gasifier through partnerships with public institutions, such as Odisha Renewable Energy Development Agency (OREDA), Rural Electrification Cooperation and Madhya Pradesh State Bamboo Mission (MPSBM) for supporting the investment in implementation covering both utility grid-connected and off-grid villages in the vicinity of these potential sites. The work is also initiated with Odisha Electricity Regulatory Commission (OERC) for obtaining regulatory permission to supply electricity to nearby villages through existing utility grid with operational agreement and for higher electricity tariff based on small capacity biomass gasifier technology to meet the operational cost of these systems and make them economically viable. TERI has signed a Memorandum of Understanding with a local partner organization and owner of the micro-enterprise at each of the sites for support during and after implementation.

The experience of adapting two-stage biomass gasifier for Indian condition and context has so far demonstrated robustness of the technology with minimal maintenance and suitability for field implementation. The future now is to demonstrate a viable business model and regulatory support with local institutional involvement to bring sustainable electricity supply to grid-connected and off-grid villages.

\subsection{Research Methodology}

The methodology included consultation with public sector agencies, NGOs, district administration and site selection for implementation. The selection of sites in the three states was done with consultations stakeholder, review of secondary sources and determination of criteria, such as economic loads in the cluster, electricity availability in the villages around, presence of local NGO, biomass availability and cost, undertaking primary surveys, and analysis of collected information. Secondary data helped narrow down a few districts on the basis of status of electrification of vil- 
lages. Each state's un-electrified villages/economic clusters were mapped in consultation with state-level agencies, such as OREDA, National Rural Livelihoods Mission, Jharkhand Renewable Energy Development Agency, MPSBM, MP District Poverty Initiatives Project (MPDPIP), Odisha Tribal Empowerment \& Livelihoods Programme, Department of Rural Development, District Industries Centre, etc.

\subsection{Selection of Village Clusters}

Identification of livelihood clusters in electricity-deficit areas where production is suffering from irregular supply of electricity or is dependent on diesel-based electricity was undertaken in consultation with local organizations, such as NGOs working for the creating/development of that cluster. Site visits to the selected clusters were made for a scoping study and preliminary surveys to learn status of the livelihood activity, number of villagers involved with the activity, number of households in the villages around and other demographic data, current business model of the activity and its finances, institutional setup of the activity such as the role of the NGO or local organization, community-level groups such as self-help groups (SHGs), etc. The scoping study to find these clusters targeted livelihood activities, such as production of nutrition mix for women and children in Anganwadis, cashew processing, milk chilling and packaging, jute processing, tussar silk reeling, lemongrass oil distillation, poultry feed making, bamboo furniture making, etc. The complete list of livelihood clusters for which scoping study was done is given in Annexure 1. These production units are mostly run by women of several SHGs in the rural areas. There is irregular electricity supply in these remote areas, and the quantity and quality of the product suffer due to it. The two-stage biomass gasifier will provide regular and clean supply of electricity at a low cost, which will increase the production and their income, and this increase will improve the standard of living of the women and their families and also give them an opportunity to explore more activities and build training centres. Four such livelihood clusters given in Table 10.2 have been selected, and an extensive feasibility study has been done for implementation.

The detailed project reports of potential feasible projects were prepared to assess electricity and thermal energy requirements for machinery/process used, current status of electrification, alternate options, and challenges faced due to shortage in the livelihood cluster and payments, biomass availability and surplus details, status of electrification in the households, such as proximity of the surrounding villages and number of households for electrification, land ownership and availability for the installation of the gasifier, willingness to pay, investment, and financial calculations. An improved institutional framework has been worked out for technical and social implementation of project, as shown in Fig. 10.2. 
Table 10.2 Selected livelihood clusters

\begin{tabular}{|c|c|c|c|c|c|}
\hline S. No. & Activity & \multicolumn{2}{|l|}{ Location } & \multicolumn{2}{|c|}{ Supporting partner } \\
\hline 1. & Nutrition mix making & \multicolumn{2}{|l|}{$\begin{array}{l}\text { Rayagada district, } \\
\text { Odisha }\end{array}$} & \multicolumn{2}{|c|}{$\begin{array}{l}\text { NGO AKSSUS_-Adivasi Krushi } \\
\text { Swasthya Sikhya Unnayan } \\
\text { Samiti }\end{array}$} \\
\hline 2. & $\begin{array}{l}\text { Cashew and } \\
\text { agro-processing }\end{array}$ & \multicolumn{2}{|c|}{ Koraput district, Odisha } & \multicolumn{2}{|c|}{$\begin{array}{l}\text { NGO SPREAD_-Society for } \\
\text { Promoting Rural Education and } \\
\text { Development }\end{array}$} \\
\hline 3. & Sal leaf plate making & $\begin{array}{l}\text { Mayurbhanj distric } \\
\text { Odisha }\end{array}$ & & \multicolumn{2}{|c|}{$\begin{array}{l}\text { NGO DEEP_-Development of } \\
\text { Environment and Education } \\
\text { Project }\end{array}$} \\
\hline 4. & $\begin{array}{l}\text { Bamboo furniture } \\
\text { making }\end{array}$ & $\begin{array}{l}\text { Balaghat district, } \\
\text { Madhya Pradesh }\end{array}$ & & \multicolumn{2}{|c|}{$\begin{array}{l}\text { Madhya Pradesh State Bamboo } \\
\text { Mission }\end{array}$} \\
\hline & $\begin{array}{c}\text { TERI } \\
\text { Project Implementer } \\
\text { Technology + } \\
\text { Training }\end{array}$ & \multirow{2}{*}{$\begin{array}{l}\text { CLEMC - } \begin{array}{l}\text { Cluster Level } \\
\text { Management }\end{array} \\
\begin{array}{|c}\text { CLEMC } \\
1 \text { in each village } \\
\text { Managing revenue } \\
\text { collection }\end{array}\end{array}$} & \multirow{2}{*}{\multicolumn{3}{|c|}{$\begin{array}{c}\text { Village Households } \\
\text { Beneficiaries of } \\
\text { Electrification }\end{array}$}} \\
\hline & $\begin{array}{l}\text { Local Partner NGO } \\
\text { Social Mobilization, } \\
\text { Capacity building \& } \\
\text { Facilitation }\end{array}$ & & & & \\
\hline & $\begin{array}{l}\text { SHG Federation } \\
\text { Administration \& } \\
\text { Management }\end{array}$ & & \multicolumn{2}{|c|}{$\begin{array}{l}\text { Micro Enterprises } \\
\text { productive } \\
\text { uses \& income } \\
\text { generation activities }\end{array}$} & \\
\hline
\end{tabular}

Fig. 10.2 Implementation institutional structure

\subsection{Koraput, Odisha}

Implementation of the two-stage biomass gasifier in Koraput has started in Odisha. The gasifier will support a new livelihood cluster of processing cashew, pulses and rice to sell directly to the market, which would have not been possible without a regular supply of electricity. As of now, there is no processing happening due to very poor voltage, and the villagers are just drying the shelled cashew for a few days and selling them to middlemen at the weekly market. This does not give them enough income. Processing of the cashew will increase their profit by over $500 \%$. This activity will be owned and run by women SHGs of the villages nearby. A picture 

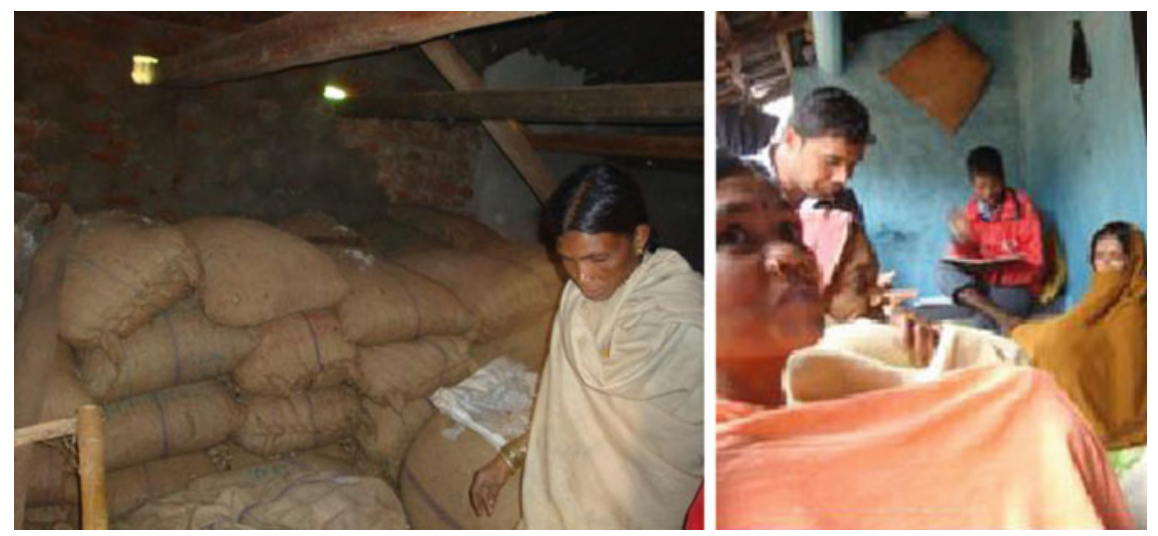

Fig. 10.3 Cashew stored for selling and the local family involved

of cashew stored in gunny bags along with tribal family involved in this activity is given in Fig. 10.3.

With a sustained business model and a self-sufficient power generation system, the community can identify other activities that are possible, which will employ even more women from more villages and increase their incomes in the long run.

The livelihood activity being initiated with the help of the biomass gasifier will be operated and managed by a women's SHG federation called Kasturaba Mahila Maha Sangh. This will give the women employment and an identity outside of their role in taking care of their households. They will be the earning members of their families and have a community support to be independent. These women will be given training on how to use the equipment to process cashew, pulses and rice. They will be taught from start to finish of making the product and packaging it and also on how to manage the finances of the business. The operators selected, women in the SHGs and the villagers have shown eagerness to learn these new skills and also signed a resolution of the same.

\subsection{Mayurbhanj, Odisha}

Sal leaf plate making in Mayurbhanj in Odisha will start with the implementation of the gasifier as there is no supply of electricity in this village. Once the gasifier is installed, the forest department will support initiation of sal leaf plate making by the SHGs. Pictures of the tribal women involved in sal leaf collection and manual stitching operation are shown in Fig. 10.4. The electricity provided by the gasifier will increase their annual income by $300 \%$. 

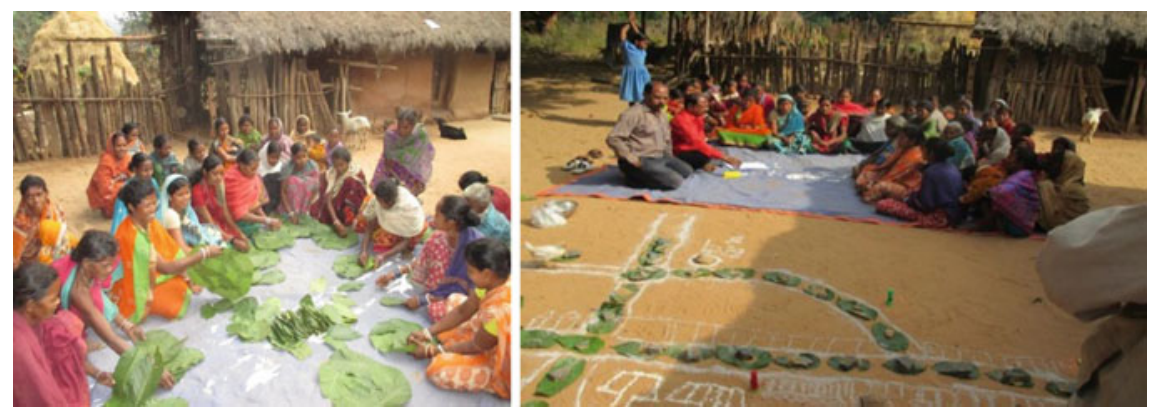

Fig. 10.4 Tribal women in manual stitching of sal leaf plates activity

\subsection{Balaghat, Madhya Pradesh}

MPSBM will support TERI in implementing the gasifier for the making of bamboo furniture (as in Fig. 10.5) in rural areas of Balaghat district. Men and women from nearby villages come to work in the factory that makes bamboo furniture. In the process, some bamboo waste is also generated, which can be used as fuel for the gasifier, thus making the factory self-sufficient in the energy requirements.

Under the project, full ownership of the power plant of two-stage biomass gasifier rests with the SHG federation. This body will have the sole responsibility of managing the affairs of the gasifier system for running of the bamboo furniture making factory, which is their sole livelihood activity. With the revenue generated by the sale of electricity and the income from by the sale of their products, they will be in a strong position to pay for the salary of the operator, the biomass supply and maintenance. This will allow them to be completely self-sufficient in their activity.
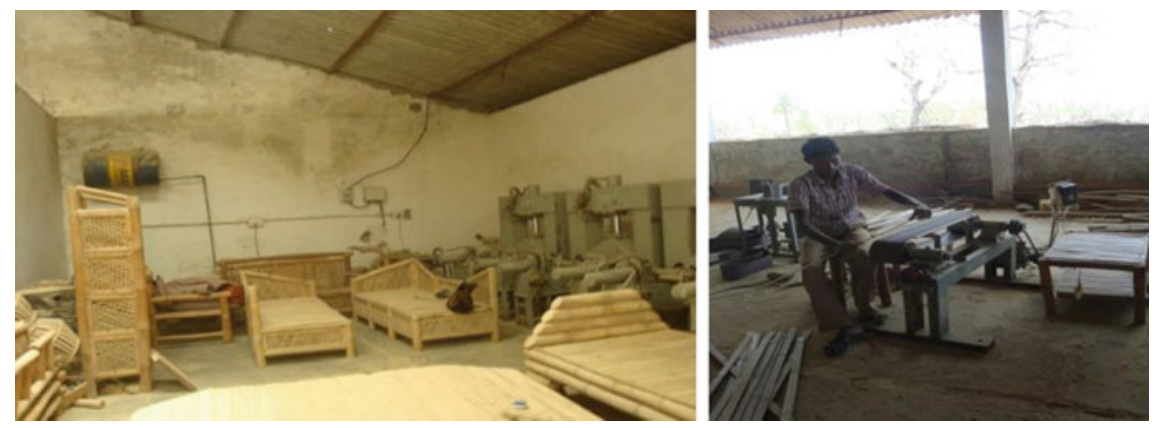

Fig. 10.5 Making of bamboo furniture 


\subsection{Potential Development Impact}

The lack of access to electricity is a major inhibitor to achieving equitable growth and building resilience of poor and vulnerable communities. With a regular supply of electricity in villages, the rural households will have immediate access to basic comforts of lights, fans and charging point, increasing their standard of living. This will gradually help them enhance livelihood opportunities even during nighttime to increase income.

Through the project, TERI and Swiss Agency for Development and Cooperation (SDC) will instal this technology in four livelihood clusters run by women SHGs in villages of Odisha and Madhya Pradesh. The two-stage gasifier of 20-40 kW will support the electrical and thermal needs of the commercial activity and electricity supply in villages around of project site. The livelihood activities being supported and initiated with the help of the biomass gasifier will be operated and managed by a women's SHG federation. This will give the women employment, improve productivity, reduce drudgery, improve health and give an identity outside of the house. They will be the earning members of their families and have community support to be independent.

\subsection{Rayagada, Odisha}

The nutrition mix (chhatua) making is run and owned by the women of an SHG Federation-Maa Dharani Mahila Maha Sangh (MDMMS) in Bissamcuttack block of Rayagada district in Odisha. A Self-Help Group (SHG) is made by women in a village to come together to have regular meetings in which they made savings to open a bank account to have the ability to take loans. These groups were made for women empowerment, a forum where women could feel united to share their problems, find solutions and make ideas for livelihood activities a reality. An SHG Federation is a block level forum where all the SHGs from all the villages in a block come together.

The nutrition mix produced by MDMMS is provided to 75 Anganwadi centres, which then provides this dry take-home ration to pregnant and lactating mothers, infants and children under the Integrated Child Development Scheme of the government. Anganwadi is a government-sponsored child-care and mother-care programme in India. It caters to children in the 0-6 age group. The word 'Anganwadi' means 'courtyard shelter' in Hindi. They were started by the Government of India in 1975 as part of the Integrated Child Development Scheme programme to combat child hunger and malnutrition. The Anganwadi centres provide hot meal to the children and a dry take-home ration. This dry ration is the nutrimix that MDMMS produces for pregnant and lactating mothers, infants and children. The picture showing the women involved in manual cleaning of grains and milling of cleaned grains is shown in Fig. 10.6. 

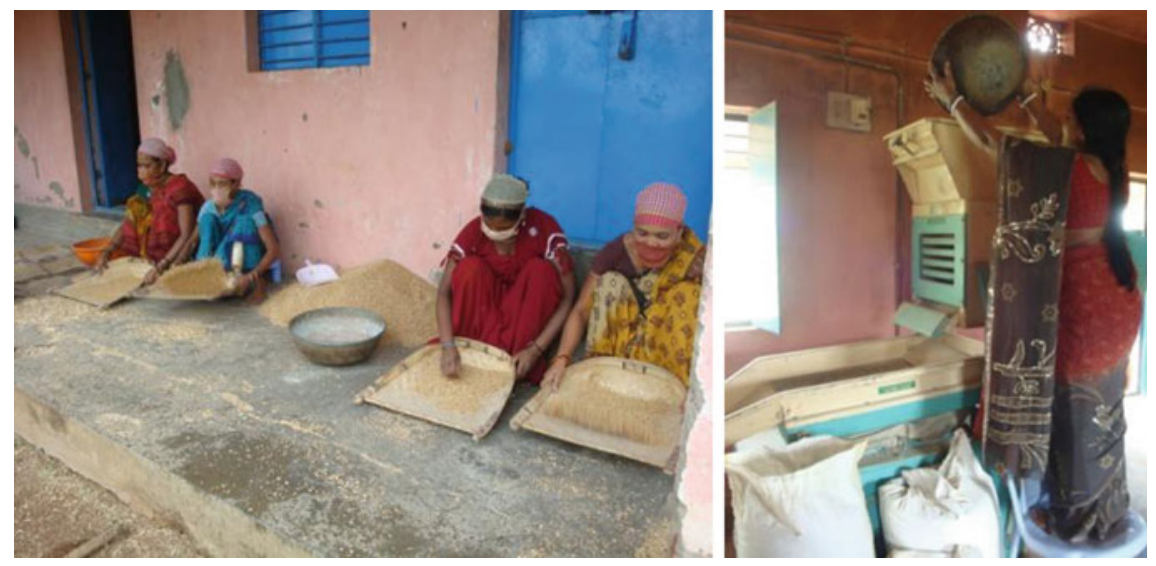

Fig. 10.6 'Nutrimix' making by members of MDMMS

There is irregular electricity supply in this area, and the quantity and quality of the product suffer due to it. The two-stage biomass gasifier will provide regular and clean supply of electricity at a low cost, which will increase the production and their income by over $500 \%$. The increase in production will support more women and children at the Anganwadi centres, and the increase in the income generated will improve standard of living of the workers and give them an opportunity to explore more activities and build training centres.

The two-stage gasifier has already been installed and is running at the site as shown in Fig. 10.7. The project aims to supply the surplus electricity to nearby villages. The villages in the vicinity of project sites are electrified through utility grid but the availability of electricity in these villages is erratic and irregular, particularly during evening time. In order to supply the surplus electricity, two villages, namely Sindhitota and Karli, were identified and found technical feasibility to connect with biomass gasifier system using utility grid. A tariff petition has been submitted to OERC for permission of grid integration and tariff gap funding for household electrification through the gasifier. This involves obtaining regulatory approval from OERC for project-specific tariff for electricity generation from biomass gasifier, approve the electricity generated by the biomass gasifier to be supplied to the village using distribution assets of the DISCOM to be considered as deemed supply of the DISCOM and arrangement to allow interconnection of gasifier supply system to LT side of distribution transformer in a safe and secure manner. The project team is currently in dialogue with different stakeholders and process of completing the necessary formalities.

The gasifier is able to reduce the fuelwood consumption in grain drying by $65 \mathrm{~kg} / \mathrm{h}$ with monthly saving of Rs. 3250 per month. The batch time is also reduced by $25 \%$ because of better heat supplied through biomass gasifier. Indoor air quality has noticeably improved but not quantified. The MDMMS is now planning to expand the production capacity by adding Haldi (turmeric) processing unit in their facility and increased quota for processing nutrition mix production. 


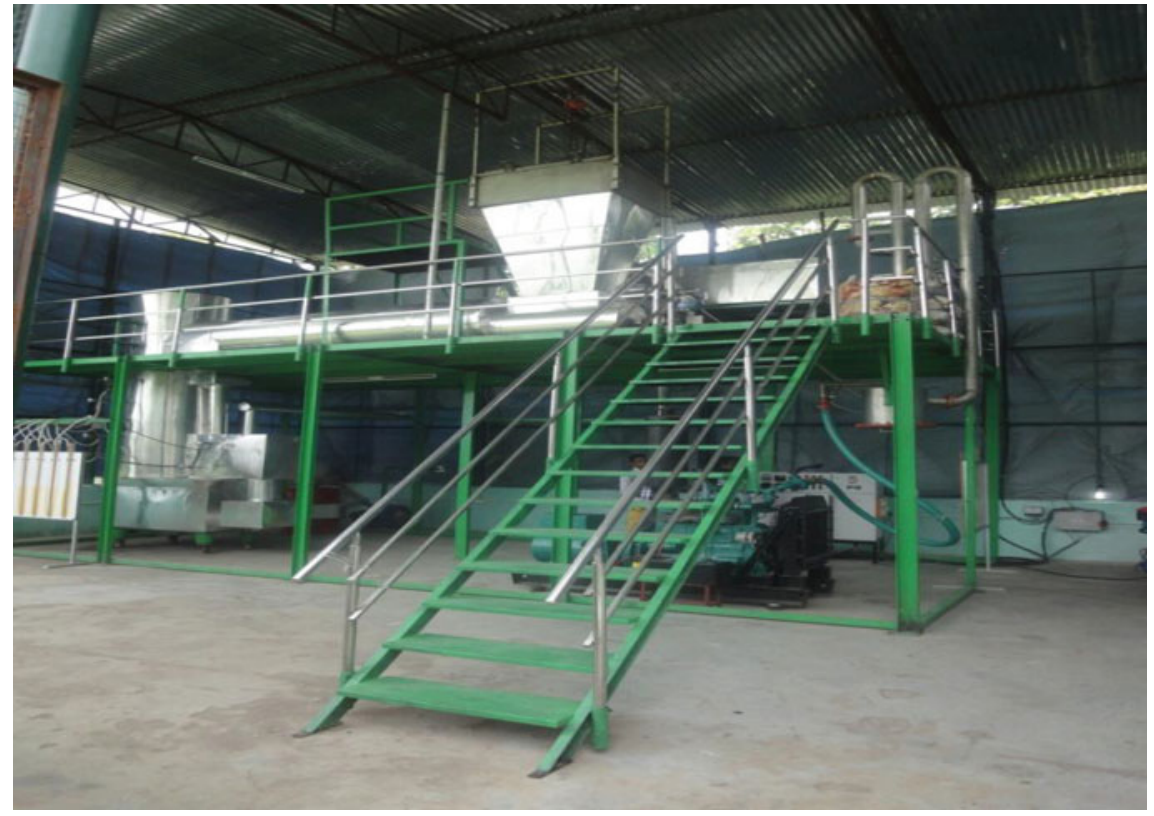

Fig. 10.7 Two-stage biomass gasifier in Rayagada, Odisha

\subsection{Recommendation for Future Research and Application in Practice}

Universal electricity access needs a rural energy services model that should be for lighting/consumption plus economic/productive loads and compatible or integrated with grid. After the first successful implementation of the two-stage biomass gasifier in Rayagada, Odisha, three more are being implemented in the selected sites in both grid and off-grid areas along with viability gap funding by the state government. The project replicates installation of two-stage biomass gasifier in four remote areas in the states of Odisha and Madhya Pradesh in India. This is a pilot programme that will be the pathway to scale up this methodology to implement it in other parts of India and other countries. Monitoring and impact evaluation will be done for the technology as well as of the business model of the livelihood activity. Learning from these four pilot implementation projects, this model should be scaled up for more villages in India to support income-generating activities and improved electricity supply, specifically for women and provide energy access to households.

Second, the existing off-grid biomass projects establish to interface with the utility grid, it will considerably increase the viability and sustainability and further improve the electricity access for the households and livelihood activities in the rural areas. The project has already taken up policy work related to creating synergy between utility grid supply and biomass gasifier based DDG systems at existing village level. 
The concept is well received by OREDA and is now also being planned for SPV-based electrification projects implemented by OREDA in the state of Odisha.

There is a need for policy and regulatory interventions of the state government to ensure integration of decentralized renewable energy generation/distribution with mainstream electricity distribution and skills development programme to include biomass energy for developing a cadre of local entrepreneurs for operation and management.

The fiscal incentives available under various schemes under different ministries of the Government of India can help achieve large-scale implementation of such models. The Ministry of New and Renewable Energy recently launched a programme to promote implementation of projects on renewable energy for rural livelihoods with provision of up to $65 \%$ investment subsidy to cover the renewable energy system cost. The Ministry of Micro, Small and Medium Enterprises is operating a scheme namely 'Credit Linked Capital Subsidy Scheme (CLCSS)' for technology upgradation of micro- and small enterprises. The scheme aims at facilitating technology upgradation of micro- and small enterprises (MSEs) by providing $15 \%$ capital subsidy (limited to maximum Rs. 15 lakhs) for purchase of plant and machinery.

The installation of the two-stage biomass gasifier has a huge potential and need for scaling up and replication in other sectors and also abroad. This technology with our existing business model of targeting rural livelihood clusters and household electrification can be beneficial for many developing countries, such as Myanmar, Nepal, Bangladesh, Kenya, Burkina Faso and other African countries. It can also be used purely for rural electrification or captive livelihood clusters.

\section{Annexure 1}

Livelihood clusters in which scoping study was done

\begin{tabular}{l|l|l|l}
\hline S. No. & Cluster activity & NGO/agency involved & Location \\
\hline 1. & Nutrimix making & AKSUSS & Rayagada, Odisha \\
\hline 2. & Cashew processing & SPREAD & Koraput, Odisha \\
\hline 3. & Cashew processing & Vasundhara & Nayagarh, Odisha \\
\hline 4. & Red chilli processing & Vasundhara & Sambalpur, Odisha \\
\hline 5. & Nutrimix making & ORMAS & Puri, Odisha \\
\hline 6. & $\begin{array}{l}\text { Bamboo products } \\
\text { making }\end{array}$ & ORMAS & Puri, Odisha \\
\hline 7. & Rural electrification & $\begin{array}{l}\text { Forest Department and } \\
\text { CPRD }\end{array}$ & Mayurbhanj, Odisha \\
\hline 8. & Rural electrification & $\begin{array}{l}\text { Forest Department and } \\
\text { DEEP }\end{array}$ & Keonjhar, Odisha \\
\hline
\end{tabular}




\begin{tabular}{l|l|l|l}
\hline S. No. & Cluster activity & NGO/agency involved & Location \\
\hline 9. & $\begin{array}{l}\text { Lemongrass oil } \\
\text { distillation }\end{array}$ & KGVK & Ranchi, Jharkhand \\
\hline 10. & Stone crushing & KGVK & Ranchi, Jharkhand \\
\hline 11. & Tussar silk reeling & Jharcraft & Saraikela-Kharsawan, Jharkhand \\
\hline 12. & Chiwda making & Women Line & Dumka, Jharkhand \\
\hline 13. & Nutrimix making & Women Line & Dumka, Jharkhand \\
\hline 14. & Bamboo basket making & Women Line & Dumka, Jharkhand \\
\hline 15. & Lift irrigation & Samvad & Deoghar, Jharkhand \\
\hline 16. & School and hostel & Sarva Shiksha Abhiyan & Ranchi, Jharkhand \\
\hline 17. & Milk chilling & MPDPIP & Shivpuri, Madhya Pradesh \\
\hline 18. & Poultry feed making & MPDPIP & Sidhi, Madhya Pradesh \\
\hline 19. & Agro processing & CIAE \& MPVS & Chhindwara, Madhya Pradesh \\
\hline 20. & Bamboo furniture & MPSBM & Balaghat, Madhya Pradesh \\
\hline 21. & Baming & MPSBM & Harda, Madhya Pradesh \\
\hline
\end{tabular}

\section{References}

Dhingra, S. \& Tanvir, B. (2014, October 2). Electrification through two-stage biomass gasifier: Opening livelihood opportunities for rural communities in India. Akshay Urja (Magazine by Ministry of New and Renewable Energy, Government of India) 8, 26-27.

Ministry of New and Renewable Energy, Government of India. (2015). Tentative StateWise Break-Up of Renewable Power Target to be Achieved by the Year 2022. Available from: http://mnre.gov.in/file-manager/UserFiles/Tentative-State-wise-break-up-of-RenewablePower-by-2022.pdf. Accessed November 6, 2015.

World Bank. (2011). India: Biomass for sustainable development; lessons for decentralized energy delivery; village energy security programme.

Open Access This chapter is licensed under the terms of the Creative Commons Attribution 4.0 International License (http://creativecommons.org/licenses/by/4.0/), which permits use, sharing, adaptation, distribution and reproduction in any medium or format, as long as you give appropriate credit to the original author(s) and the source, provide a link to the Creative Commons license and indicate if changes were made.

The images or other third party material in this chapter are included in the chapter's Creative Commons license, unless indicated otherwise in a credit line to the material. If material is not included in the chapter's Creative Commons license and your intended use is not permitted by statutory regulation or exceeds the permitted use, you will need to obtain permission directly from the copyright holder.

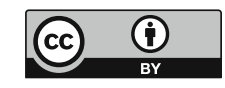

